\title{
ULTRASTRUCTURAL LOCALIZATION AND BIOCHEMICAL FEATURES OF IMMUNOREACTIVE LEU-ENKEPHALIN IN MONKEY DORSAL HORN ${ }^{1}$
}

\author{
NEIL ARONIN, ${ }^{2}$ MARIAN DiFIGLIA, ANTHONY S. LIOTTA, ${ }^{*}$ AND JOSEPH B. MARTIN \\ Department of Neurology, Massachusetts General Hospital, Boston, Massachusetts 02114 and the ${ }^{*}$ Endocrine Section, \\ Mount Sinai School of Medicine, New York, New York 10029
}

\begin{abstract}
Leu-enkephalin is an opioid peptide that has been found to modulate nociception in the spinal cord. Both pre- and postsynaptic interactions by enkephalins have been proposed. By the peroxidase . anti-peroxidase immunocytochemical method, we studied the distribution and ultrastructure of neuronal elements in the monkey dorsal horn to elucidate possible morphological substrates for pustulated opioid actions. Biochemical analysis of immunoreactive Leu-enkephalin-like peptides in the cord was performed to characterize the forms present in labeled neurons and terminals. At the light microscopic level, fiber immunostaining was found in most areas of gray matter, especially in laminae I to V, and in the dorsolateral funiculus. Cell bodies were located in laminae I, II, III, and V. At the ultrastructural level, in the superficial dorsal horn, we found that neurons with Leuenkephalin receive numerous types of axon inputs, some of which have been identified previously as originating from the dorsal root. Leu-enkephalin terminals formed primarily axosomatic and axodendritic synapses and less frequently synapsed with other axons. With the same Leu-enkephalin antiserum as used in the immunocytochemistry, a peptide physicochemically similar to intact Leuenkephalin and two larger Leu-enkephalin-like peptides were identified in monkey spinal cord extracts. It is likely that a family of Leu-enkephalin-like peptides is present in monkey spinal cord and that the labeled elements may contain any or all of these substances. It is concluded that both pre- and postsynaptic physiologic effects of Leu-enkephalin are possible, although the preponderance of axodendritic synapses favors a principal postsynaptic site of action. The anatomical results suggest that neurons containing immunoreactive Leu-enkephalin in the dorsal horn, some of which may receive input from primary afferents, modulate nociception by directly synapsing with cells of origin of the spinothalamic tract and also by interacting with primary afferent terminals.
\end{abstract}

Leu-enkephalin, a pentapeptide in the family of endogenous opioids (Hughes et al., 1975; Kosterlitz and Hughes, 1975), has been measured in the dorsal horn of the monkey spinal cord (Simantov et al., 1976). At the light microscopic level, immunocytochemical studies in the rat have demonstrated that enkephalin fibers and

' This work was supported by National Institutes of Health Grants 5 F32 AM 06143-02, NS 16367, and AM 262-52. We wish to thank Mr. Stuart Fitzgibbon, Mr. Michael O'Connell, Ms. Jan Carey, and Ms. Kathleen Sullivan for their able technical assistance. We appreciate the generosity of Dr. Dennis Landis for making available to us the electron microscopic facility in the Laboratory of Neurocytology of the Massachusetts General Hospital. We gratefully acknowledge Dr. Roderick Bronson and the New England Regional Primate Center, Southborough, MA 01772 (National Institutes of Health Grant RR-00168 from the Division of Research Resources) for the gifts of tissue used in this study.

${ }^{2}$ To whom correspondence should be addressed at Neuroendocrine Laboratory, Research 4, Massachusetts General Hospital, Boston, MA 02114 . neurons are predominantly in the marginal layer (lamina I) and substantia gelatinosa (lamina II) (Elde et al., 1976; Watson et al., 1977; Hökfelt et al., 1977a, b; Sar et al., 1978), areas also known to contain high levels of substance $P$, a putative neurotransmitter of nociception (for review, see Nicoll et al., 1980). It has been proposed that the coincidental localization of both enkephalin and substance $\mathrm{P}$ in the outer dorsal horn is associated with a role of enkephalin in modulating nociceptive input (Hökfelt et al., 1977b). Evidence that opiate receptors are located in the superficial dorsal horn (Atweh and Kuhar, 1977) and that their levels decline after severing the dorsal root have supported the theory that enkephalins act directly upon the primary afferent in an axoaxonic synapse (LaMotte et al., 1976; Jessell et al., 1979). In vitro studies where enkephalin prevents release of substance $P$ from dorsal root cells in culture (Crain et al., 1978; Mudge et al., 1979) have provided further evidence for the existence of presynaptic inhibition. On the other hand, recent physiologic data have suggested that enkephalin acts at 

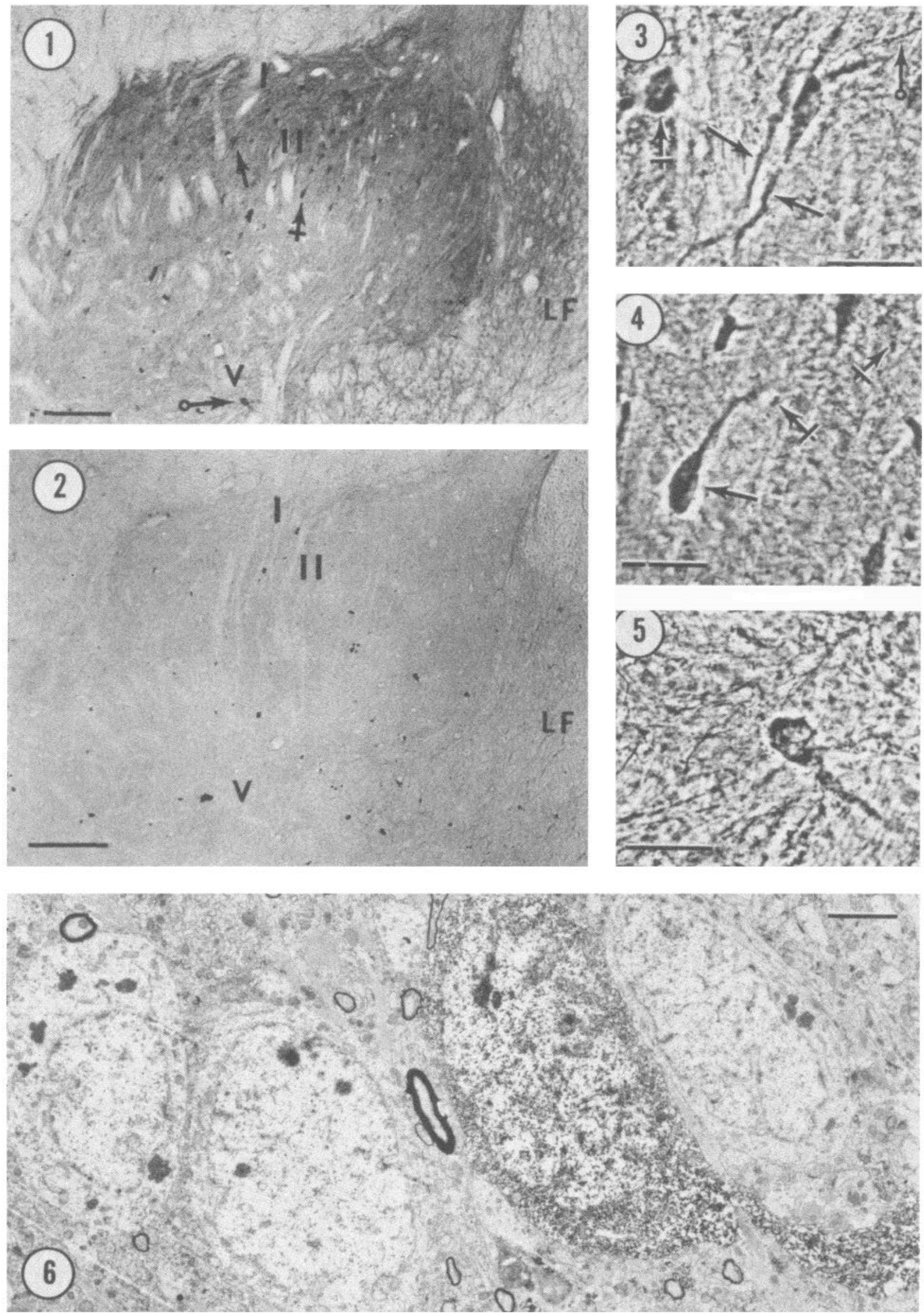
postsynaptic sites in spinal dorsal horn (Zieglgänsberger and Tulloch, 1979) and trigeminal nucleus (Henry et al., 1980).

At the electron microscopic level in the rat dorsal horn, immunoreactive enkephalin has been localized to axon terminals (Pelletier and LeClerc, 1979) and found to form synapses with dendrites and cell bodies (Hunt et al., 1980). To date, there is no information on enkephalin containing perikarya or morphological evidence for direct action by enkephalin on sensory afferent terminals. We investigated by the immunoperoxidase method (Sternberger, 1974) the ultrastructure of neurons and fibers that contain Leu-enkephalin in the outer dorsal horn of the monkey spinal cord. Furthermore, biochemical characterization of immunoreactive (IR) Leu-enkephalin (Leu-enk) was undertaken to identify more precisely the peptide(s) recognized by the antiserum employed.

\section{Materials and Methods}

\section{Animals}

Observations were made on eight monkeys (Macaca cynamologous) weighing 2.5 to $6 \mathrm{~kg}$. Tissue from one monkey was fixed by immersion in $3 \%$ paraformaldehyde brought to $\mathrm{pH} 7.3$ with phosphate buffer. Another was perfused with $10 \%$ formalin and four others with 3 to $4 \%$ paraformaldehyde in phosphate buffer ( $\mathrm{pH} 7.3$ ) to which $0.2 \%$ glutaraldehyde had been added. Two monkeys were used for biochemistry (see below). The brains and other organs of these animals also were used in other scientific. experiments, none of which affected the integrity of the spinal cord.

\section{Immunocytochemistry}

The protocol was adapted from the method of Pickel et al. (1977). Six to $48 \mathrm{hr}$ following fixation, transverse sections from the cervical and lumbar enlargements were cut with a Vibratome (Hökfelt and Ljungdahl, 1972) which contained cold phosphate buffer $(0.15 \mathrm{M}, \mathrm{pH} 7.3)$. Sections were stored in buffer for up to $2 \mathrm{hr}$, washed twice in $0.2 \mathrm{M}$ Tris (tris(hydroxymethyl)aminomethane)/ saline (TS; pH 7.6), and then transferred to $30 \%$ normal goat serum in TS for $30 \mathrm{~min}$. After two washes in TS, sections were incubated for 18 to $36 \mathrm{hr}$ at $4^{\circ} \mathrm{C}$ in Leu-enk antiserum (code: BF-G; Bio-Flex) at a dilution of 1:400 (see below for antisera characterization). For each animal, control sections were processed in the same manner but without exposure to the Leu-enk antiserum or were treated with antiserum which had been pre-absorbed for 1 to $6 \mathrm{hr}$ with excess synthetic Leu-enk. Following two washes in TS with $1 \%$ normal goat serum, sections were transferred to goat anti-rabbit IgG (diluted 1:20) for 30 min, washed in TS, and incubated in a solution of peroxidase-anti-peroxidase (PAP) complex at 1:30 dilution. After another brief wash, tissue was passed to diaminobenzidine $(0.013 \%)$ containing $\mathrm{H}_{2} \mathrm{O}_{2}(0.003 \%)$ for 6 to 10 min. All sections then had three 10 -min washes in distilled water.

Sections for light microscopy were mounted on glass slides with $0.5 \%$ gelatin. Those prepared for electron microscopy from the glutaraldehyde-fixed tissue were cut into smaller pieces, incubated for $1 \mathrm{hr}$ in $2 \%$ osmium tetroxide, stained in $1 \%$ uranyl acetate for $2 \mathrm{hr}$, and embedded in a thin sheet of Epon supported by a plastic coverslip. Areas with IR Leu-enk were selected by light microscopy, cut out from the plastic, and mounted on Epon blocks. Serial thin sections were cut and supported by Formvar-coated slot grids. Sections were examined routinely in the electron microscope prior to staining with lead citrate.

\section{Biochemical characterization of immunoreactive Leu-enk}

Tissue preparation. Cervical and lumbar spinal cord $(n=2)$ was placed immediately in $0.2 \mathrm{M} \mathrm{HCl}$ and frozen for subsequent analysis. After thawing and the addition of human serum albumin (hSA) to a final concentration of $0.1 \%$, the tissue was homogenized with a Teflon pestle in a siliconized glass tube. An aliquot of the unspun homogenate was removed for protein determination (Lowry et al., 1951). After the remaining homogenate was spun at $10,000 \times g\left(45 \mathrm{~min}, 10^{\circ} \mathrm{C}\right)$, a portion of the clear supernatant was titrated to $\mathrm{pH} 5.5$ to 7.0 with $1 \mathrm{M}$ $\mathrm{NaOH}$, recentrifuged, and assayed in the Leu-enk radioimmunoassays (RIA; see below). The bulk of the supernatant was lyophilized in aliquots corresponding to approximately $200 \mathrm{mg}$ of original tissue.

Analytic scheme. Lyophilized material was reconstituted in $0.05 \mathrm{M} \mathrm{Na} \mathrm{HPO}_{4}$ and adjusted to $\mathrm{pH} 7.5$ with $\mathrm{Na}_{2}$ EDTA containing $0.8 \%$ hSA, $0.5 \%$ Triton X-100, and

Figure 1. Enkephalin in the cervical dorsal horn. A $20-\mu \mathrm{m}$ Vibratome section shows IR Leu-enk fibers primarily in laminae I and II and the dorsal region of the lateral funiculus $(L F)$. Immunostained cell bodies appear mostly in outer lamina II and the lateral region of lamina V. Arrow, crossed arrow, and ringed arrow indicate regions shown in Figures 3 , 4, and 5, respectively. Scale, $200 \mu \mathrm{m}$.

Figure 2. Pre-incubation control. Section near to one shown in Figure 1 showed an absence of IR Leu-enk fibers and cell bodies when Leu-enk antisera was pre-absorbed with excess Leu-enk peptide prior to incubation with tissue. Scale, $200 \mu \mathrm{m}$.

Figure 3. IR enk cell bodies (corresponds to region of arrow in Fig. 1). Somata with a fusiform shape and thick dendrites (arrous) which are oriented in a dorsoventral direction appear in outer lamina II. An ovoid-shaped soma (crossed arrou) and beaded axonal processes (ringed arrow) are also present. Phase contrast photography was used. Scale, $30 \mu \mathrm{m}$.

Figure 4. Enkephalin somata (corresponds to area of crossed arrow in Fig. 1). Cell bodies with IR Leu-enk in deeper region of lamina II exhibit a fusiform shape (arrow). Punctate IR axonal elements (crossed arrows) are numerous. Phase contrast photography was used. Scale, $30 \mu \mathrm{m}$.

Figure 5. IR Leu-enk in lamina V (area indicated by ringed arrow in Fig. 1). The labeled neuron and numerous axonal processes typify the appearance of this region in most positive sections. Phase contrast photography was used. Scale, $30 \mu \mathrm{m}$.

Figure 6. Enkephalin somata in the substantia gelatinosa. Immunostained neuron with fusiform shape and emerging dendrite has large invaginated nucleus and is near three unlabeled cell bodies, one of which (at right) is contiguous. Scale, $2 \mu$ m. 

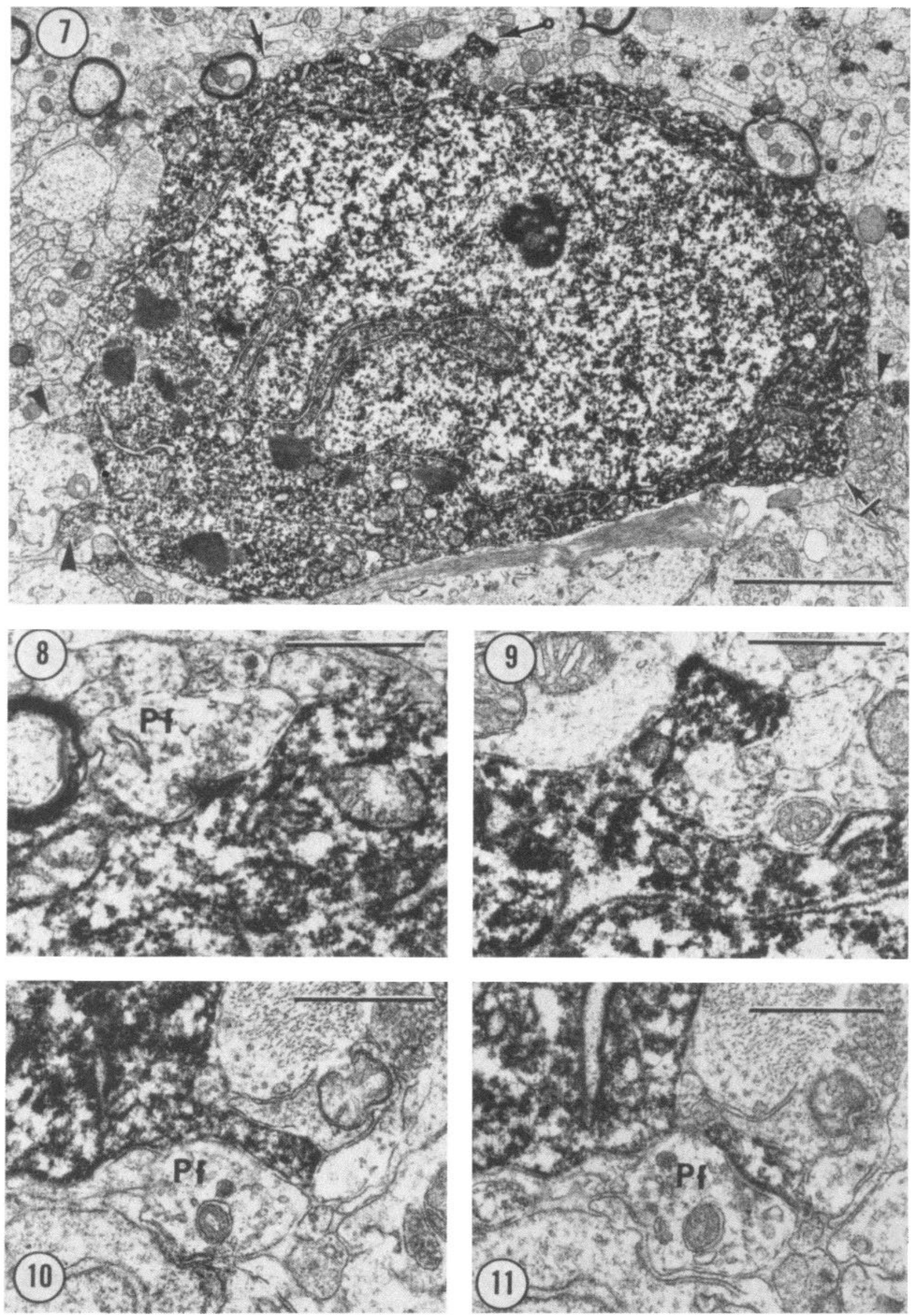
$0.5 \%$ dithiothreitol (500 liters). Ten microliters of Leuenk antiserum (code: BF-GF) was added and, after overnight incubation, anti-rabbit IgG was added to effect immunoprecipitation (Liotta et al., 1979) of the IR Leuenk. Ten microliters of BF-GF completely precipitates 12 pmol of synthetic Leu-enk; $8 \mathrm{nmol}$ of unlabeled Leu-enk inhibits the binding (95\%) of ${ }^{125}$ I-Leu-enk $(0.2 \mathrm{pmol})$. To separate the IR Leu-enk peptides, the immunoprecipitates were dissolved in $8 \mathrm{M}$ urea in $2 \mathrm{~N} \mathrm{CH}_{3} \mathrm{COOH}$, heated for $3 \mathrm{~min}$ in a boiling $\mathrm{H}_{2} \mathrm{O}$ bath, and left at room temperature for 2 to $3 \mathrm{hr}$. The immunoglobulins were removed by precipitation with $\left(\mathrm{NH}_{4}\right)_{2} \mathrm{SO}_{4}$ (30\% saturated solution) or by passage of the clear solution through a Waters $\mathrm{C}_{18}$ Sep-Pak, washed with $0.1 \%$ trifluoroacetic acid, and eluted with $70 \% \quad \mathrm{CH}_{3} \mathrm{CN} /$ formate/triethylamine. The $\mathrm{CH}_{3} \mathrm{CN}$ was removed with a gentle stream of $\mathrm{N}_{2}$. The sample was diluted to $2 \mathrm{ml}$ with high pressure liquid chromatography (HPLC) solvent (see below) and then injected into the HPLC column. Aliquots of individual column fractions $\left(1 \mathrm{ml} \mathrm{min}^{-1}\right.$ flow rate fractions collected every $0.5 \mathrm{~min}$ ) were quantified in the Leu-enk RIA. IR Leu-enk material eluting in regions not corresponding to authentic Leu-enk standard were pooled and lyophilized. This material was characterized further in two ways: (1) sodium dodecyl sulfate-polyacrylamide gel electrophoresis (SDS-PAGE) to estimate molecular weights and (2) overnight trypsinization followed by reverse phase high pressure liquid chromatography (HPLC) in order to identify any generated IR Leu-enk fragments.

Antisera specificity. Two Leu-enk antisera were employed. BF-G at 50\% displacement and 1:40,000 dilution exhibits molar cross-reactivities of $<0.2,3$, and $<0.3 \%$ with Met-enk, Leu-enk-Arg ${ }^{6}$ (Peninsula Laboratories), and dynorphin-(1-13) (a gift from Dr. A. Goldstein, Addiction Research Foundation, Palo Alto, CA), respectively. A free $\mathrm{Leu}^{5}$ residue appears to be required for full immunological recognition. At 1:100,000 dilution (50\% displacement), the second antiserum, BF-GF exhibits cross-reactivities of $<0.9,32$, and $<1.2 \%$ with the above peptides and $21 \%$ with synthetic $\mathrm{Leu}^{5} \beta_{\mathrm{h}}$-endorphin. Neither antibody preparation reacts at all with $\beta_{0}$-lipotropin, $\beta-, \alpha-$, or $\delta_{0}$-endorphin, or pACTH-(1-39). BF-G was utilized for immunochemistry, BF-GF was used for immunoprecipitation, and both were employed for RIA.

Trypsinization. Trypsinization of HPLC-separated peptides was performed as described by Lewis et al. (1978).

Reverse phase HPLC. A dual pump model 332 Beckman microprocessor-controlled HPLC system equipped with a 2 -ml sample loop and a $0.46 \times 25 \mathrm{~cm}$ Ultrasphere
ODS column was employed. Two gradient systems were used: (1) a 1-hr linear gradient from $0.5 \mathrm{M}$ formate, 0.14 $\mathrm{M}$ pyridine to $0.5 \mathrm{M}$ formate, $0.14 \mathrm{M}$ pyridine, $20 \% 1$ propanol (Lewis et al., 1979) and (2) a 1- or 2-hr linear gradient from $0.05 \mathrm{M}$ formate/triethylamine (TEA), $\mathrm{pH}$ 3.2 to $0.05 \mathrm{M}$ formate/TEA, $\mathrm{pH} 3.2,50 \% \mathrm{CH}_{3} \mathrm{CN}$.

$S D S-P A G E$. The method of Liotta and Krieger (1980) was employed.

\section{Results}

\section{Light microscopy}

Leu-enk immunoreactive elements were present in the spinal cord of all of the animals. Enkephalin-positive cell bodies were found in the posterior horn, mostly within a region 80 to $275 \mu \mathrm{m}$ from the rim of the dorsal gray matter (Fig. 1). This area in the monkey includes portions of the marginal layer or lamina I and the dorsal substantia gelatinosa or outer lamina II (Ralston, 1979). Neurons were distributed uniformly, but clusters of five to seven cells were observed occasionally. Some somata were found 30 to $60 \mu \mathrm{m}$ from the dorsal rim (lamina I) and others were observed as deep as $450 \mu \mathrm{m}$ in a region which includes inner lamina II and parts of lamina III. A few cells also were located in the lateral region of lamina $\mathrm{V}$ (Figs. 1 and 5). The number of positive neurons found in a given section varied considerably. As many as 40 were counted in a $20-\mu \mathrm{m}$ section of one dorsal horn. Somata were round or ovoid and 10 to $15 \mu \mathrm{m}$ in diameter. Some had a fusiform shape and attained $25 \mu \mathrm{m}$ in the long dimension (Figs. 3 and 4). About four thick processes (2 to $4 \mu \mathrm{m}$ ), presumably dendrites, arose from the cell bodies and could be followed up to $75 \mu \mathrm{m}$. In transverse sections, dendrites in the marginal layer were oriented horizontally, parallel to the surface of the spinal cord and, in the substantia gelatinosa, took a dorsoventral direction. Enkephalin immunoreactivity was present in secondary dendritic branches. Some of these dendrites (1.5 to $2 \mu \mathrm{m}$ thick) had a tortuous course and gave rise to spines and longer beaded processes. Occasionally, a thinner, axonlike element could be seen emerging from a labeled neuron.

Enkephalin-positive fibers and terminals were found in most parts of the gray matter. The greatest density appeared in the most superficial aspect of the dorsal horn, 60 to $125 \mu \mathrm{m}$ deep in a medial to lateral direction (Fig. 1). This region in the monkey corresponds to lamina I (Ralston, 1979). Numerous fibers were present in deeper laminae (II, III, and IV) where they could be seen surrounding some cell bodies. A relatively dense concentra-

Figure 7. Lamina II enkephalin neuron examined in serial sections. The soma exhibits a heavy accumulation of peroxidase reaction product in the nucleus, cytoplasm, and numerous emerging spines (ringed arrow and arrowheads). Arrow, ringed arrow, and crossed arrow correspond to locations in Figures 8, 9, and 10-11, respectively. Scale, $2 \mu \mathrm{m}$.

Figure 8. Axosomatic synapse. $\Lambda$ serial section near region of the arrow in Figure 7 shows a synapse formed by ierminal ( $P f$ ) which contains pleomorphic vesicles including many flat ones. Scale, $0.5 \mu \mathrm{m}$.

Figure 9. Somatic spine (at the ringed arrow in Fig. 7). The spine, which has a thin neck and small end bulb, when followed in serial sections, failed to show a synaptic input. Scale, $0.5 \mu \mathrm{m}$.

Figures 10 and 11. Somatic spine in serial sections (near region of the crossed arrow in Fig. 7). Emerging thin spine in Figure 10 is adjacent to axon terminal Pf. In Figure 11, a portion of spine head appears separated from soma and is contacted by $P f$. Scale, $0.5 \mu \mathrm{m}$. 

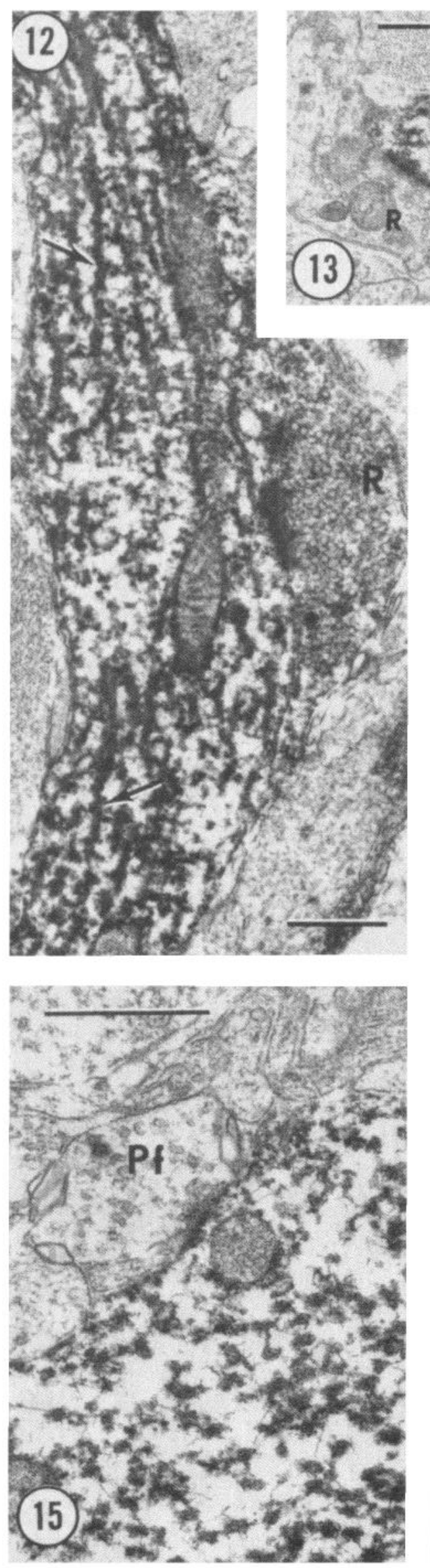
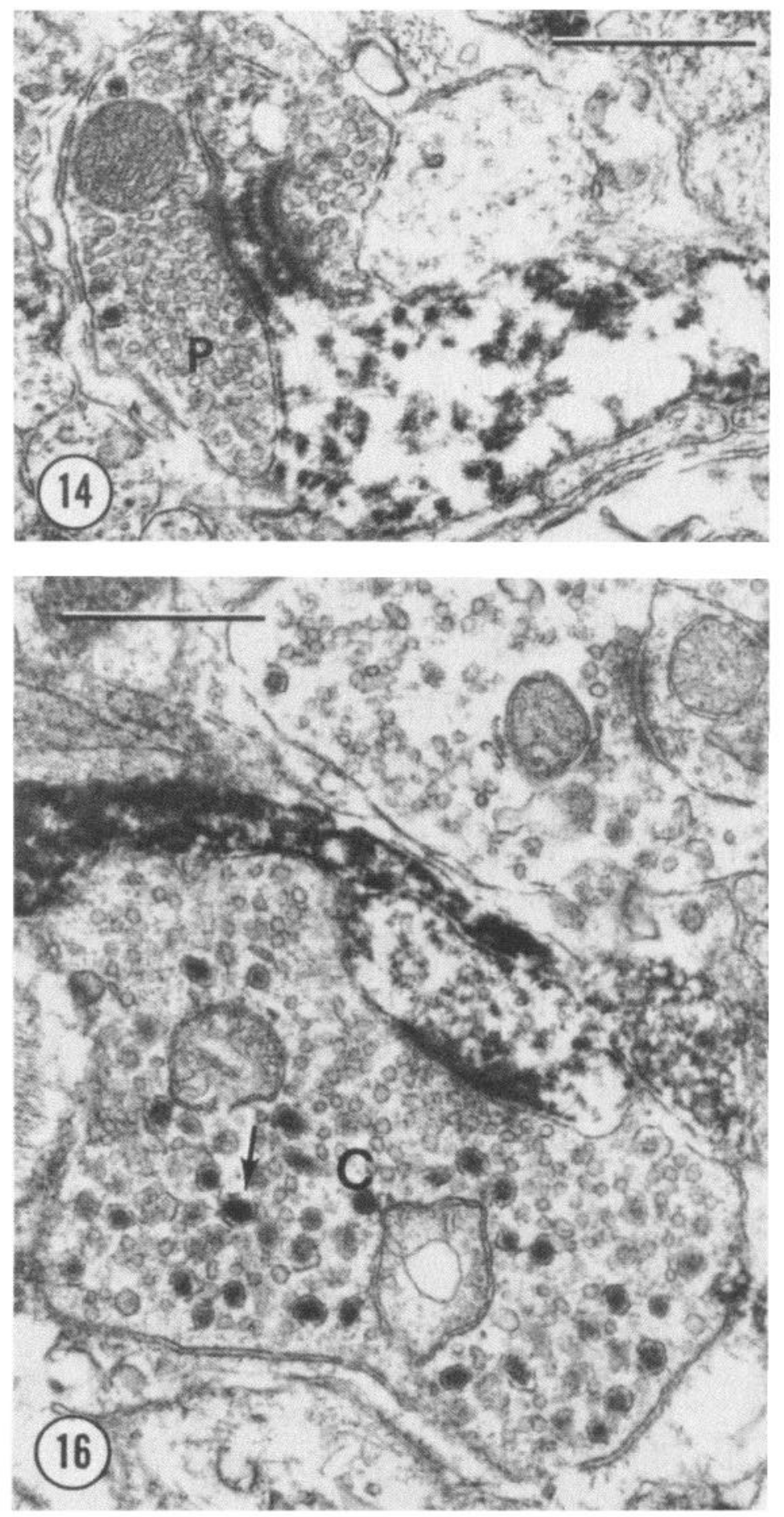
tion of processes was found in the lateral portions of lamina V (Fig. 5). Positively stained axons were observed to traverse between lamina $\mathrm{V}$ and the neighboring white matter. Enkephalin axons coursed through lamina VI and VII and, in the ventral horn (lamina IX), were found in close proximity to the cell bodies and emerging dendrites of $\alpha$ motoneurons. Terminals were numerous in lamina $\mathrm{X}$ and sparsely distributed in lamina VIII. Small bundles of IR processes crossed in the posterior commissure and a few also crossed in the anterior commissure. Many labeled fibers were found in the lateral funiculus (Fig. 1). They were concentrated heavily in a region up to $200 \mu \mathrm{m}$ from the gray matter and extended from the border of the tract of Lissauer dorsally to the level of lamina VI ventrally. Fewer processes were seen in the white matter bordering the ventral horn. Control sections failed to show specific labeling in all of the areas described above (Fig. 2).

\section{Electron microscopy}

Neurons. Enkephalin-positive neurons in lamina II exhibited peroxidase reaction product along the membranes of most of their subcellular organelles and within their nuclei (Figs. 6 and 7). The latter occupy a large portion of the perikarya and have numerous enfoldings. Cell bodies are bounded in part by glia and the outer membranes of some cells are contiguous but not synaptic with those of adjacent, unstained neurons (Fig. 6). Synapses on enkephalin cells were found infrequently. Those identified were formed by two types of terminals containing pleomorphic vesicles which were densely or loosely packed (Fig. 8; see below). Somatic spines about $0.5 \mu \mathrm{m}$ in length were numerous in some cells (Figs. 7 and 9). When followed in serial sections, some somatic spines were postsynaptic (Figs. 10 and 11).

Dendrites emerging from enkephalin cells were straight or irregular in contour. They contained numerous microtubules which were labeled heavily with the peroxidase reaction product, a feature most noticeable in sections cut along the longitudinal plane of the dendrite (Figs. 12 and 13). Dendrites also contained some small clear $(40 \mathrm{~nm})$ and large granular vesicles $(L G V ; 100 \mathrm{~nm})$, both of which were more abundant in the smaller branches (Fig. 18). Enkephalin dendrites gave rise to thin spines which extended up to $1 \mu \mathrm{m}$ in length and had small end bulbs (Fig. 14).

At least four types of vesicle-containing profiles synapse upon the enkephalin neuron. (1) Type P boutons, which formed the most frequent contacts, were about 0.5 $\times 1 \mu \mathrm{m}$ in size and were packed densely with small pleomorphic vesicles $(35 \mathrm{~nm})$ and some LGV $(100 \mathrm{~nm})$. They occasionally contacted enkephalin somata and more frequently distal dendrites and spines (Figs. 13 and 14). Synapses were characterized by a long surface contact of up to $0.6 \mu \mathrm{m}$ and by subjunctional bodies in the postsynaptic profiles. These terminals sometimes surrounded enkephalin spines and formed crest synapses (Fig. 14). Some of the boutons arose from myelinated fibers about $0.5 \mu \mathrm{m}$ in diameter (Fig. 17). (2) Large terminals (type C), 2 to $4 \mu \mathrm{m}$ in diameter, frequently contacted small enkephalin dendrites and occasionally larger branches. Two varieties were observed: Some contained loosely packed, small clear vesicles and many LGV (Figs. 16 and 18) and others with a darker matrix had numerous round vesicles $(40 \mathrm{~nm})$. Both types frequently formed the central element in which they were presynaptic to one to four enkephalin profiles and other unlabeled dendrites. (3) Boulons (type R), which were $0.5 \times$ $1 \mu \mathrm{m}$ in diameter and were filled densely with round vesicles $(40 \mathrm{~nm})$, formed synapses upon the distal branches of enkephalin cells (Fig. 13) and occasionally on their primary dendrites (Fig. 12). (4) Small profiles (type Pf), $0.5 \times 0.5 \mu \mathrm{m}$, containing few pleomorphic vesicles, many of which were flat, formed synapses with enkephalin somata (Fig. 8), somatic spines (Figs. 10 and 11), and large (Fig. 15) and small (Fig. 20) dendrites.

Many of the small enkephalin-positive dendrites which were postsynaptic to type $\mathrm{C}$ or $\mathrm{R}$ terminals contained some vesicles (Fig. 18). Occasionally these and larger enkephalin dendrites formed synapses with unlabeled dendrites (dendrodendritic; Fig. 19).

Axons. Myelinated axons, up to $1 \mu \mathrm{m}$ in diameter, which immunostained for enkephalin were seen in laminae I and II (Fig. 21). In addition, numerous small diameter unmyelinated processes $(0.1$ to $0.3 \mu \mathrm{m})$ were found coursing in bundles and throughout the neuropil (Figs. 21, 29, and 30).

Enkephalin-positive axon terminals contained many small, round, clear vesicles $(40 \mathrm{~nm})$ and few LGV. Reaction product was present around the membranes of the small vesicles and within the LGV. Boutons had a maximum size of about $1.5 \mu \mathrm{m}$ and formed asymmetric synapses with unlabeled cell bodies, dendritic shafts, and spines. Terminals were more numerous in the marginal layer where they synapsed with both large (Fig. 22) and small (Fig. 23) dendrites. Many positive boutons frequently surrounded and contacted smaller dendrites and occasionally surrounded the necks of thin spines and

Figure 12. IR Leu-enk in a proximal dendrite. Reaction product is present along microtubules (arrows) and the outer membranes of mitochondria and cisterns. Unlabeled terminal with round vesicles $(R)$ forms synapse. Scale, $0.5 \mu \mathrm{m}$.

Figure 13. Leu-enk in a distal dendrite. IR sites, which are present along microtubules $(a r r o w)$ and outer membrane of mitochondria, appear in a dendrite which receives synapses from profiles with round $(R)$ and pleomorphic $(P)$ vesicles. $S c a l e, 0.5$ $\mu \mathrm{m}$.

Figure 14. Axospinous synapse. A bouton with pleomorphic vesicles $(P)$ forms a crest synapse with neck of spine which arises from an enkephalin-labeled dendrite. Scale, $0.5 \mu \mathrm{m}$.

Figure 15. Axodendritic synapse. Terminal with loosely packed pleomorphic vesicles $(P f)$ contacts portion of a large proximal IR dendrite. Scale, $0.5 \mu \mathrm{m}$.

Figure 16. Axodendritic synapse. A type C profile, which contains small clear and large granular (arrow) vesicles, synapses with an enkephalin-labeled dendrite. The latter invaginates the $C$ bouton. Above and adjacent to both profiles, an IR enk axon courses through the neuropil. Scale, $0.5 \mu \mathrm{m}$. 

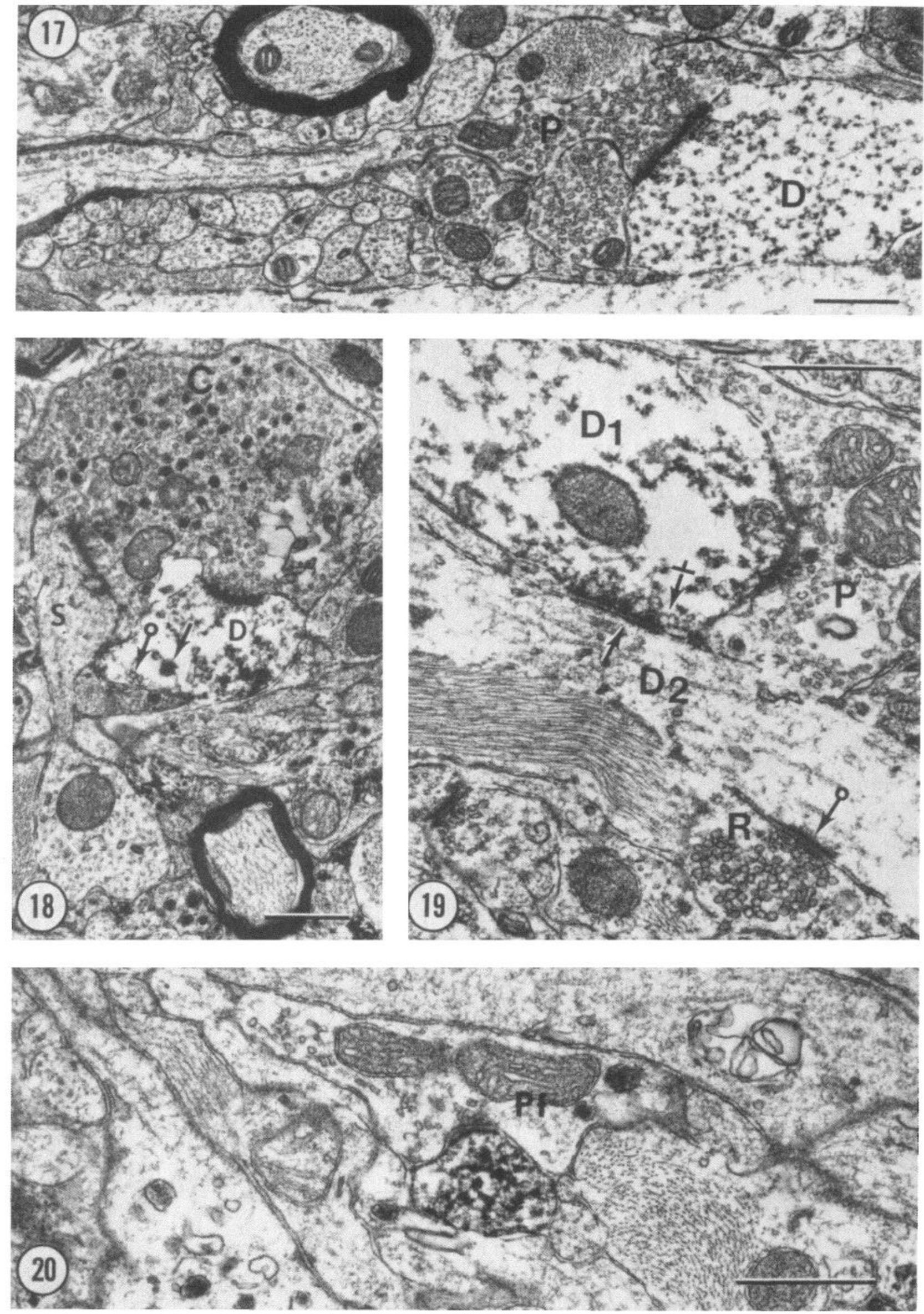
formed ring synapses (Fig. 25). Small enkephalin boutons $(0.5 \mu \mathrm{m})$ were presynaptic to unlabeled cell bodies located in laminae I and II (Fig. 24). Sometimes synapses were associated with dense bodies in the postsynaptic elements. Generally a single bouton contacted only one or two other profiles. Some dendrites and spines which were postsynaptic to enkephalin terminals also received contacts from type R (Fig. 26) and type C (Fig. 30) profiles. Enkephalin axons occasionally synapsed with other axons (axoaxonic), some of which could be identified as central terminals with LGV (Figs. 28 to 30 ). In these axoaxonic interactions, the enkephalin bouton usually invaginated the type $\mathrm{C}$ bouton. Finally, a few IR Leu-enk terminals synapsed with dendrites also positively labeled for Leu-enk (Fig. 27).

\section{Chemical characterization of IR Leu-enk in spinal cord extracts}

The unchromatographed tissue extracts contained 330 $\pm 27 \mathrm{fmol} \mathrm{mg}^{-1}$ of protein as measured by BF-GF RIA. Multiple dilutions of the extract did not run parallel with the standard in the BF-G RIA so that quantification was not possible.

HPLC. HPLC profiles $\left(\mathrm{CH}_{3} \mathrm{CN}\right.$ system $)$ revealed that the majority of the IR Leu-enk activity was distributed among three peaks (Fig. 31), one of which, designated as peptide $\mathrm{A}$, exhibited a retention time identical to synthetic Leu-enk. Both BF-GF and BF-G antisera quantified essentially the same amount of IR Leu-enk activity in peptide $\mathrm{A}$, a result consistent with its identification as authentic Leu-enk. When fractions containing peptide A were pooled, lyophilized, and run in the 1-propanol HPLC system, a homogeneous peak was found with the retention time of synthetic Leu-enk (data not shown). Two other IR Leu-enk peptides were detected (peptides B and C) in the chromatogram. Quantification of peptide B in the BF-G RIA resulted in a value $47 \%$ of that obtained in the BF-GF RIA. Peptide $C$ reacted in a nonparallel fashion in the BF-G RIA, with an apparent cross-reactivity of $<5 \%$ compared to the value obtained in the BF-GF RIA. Hence, this peptide could not be quantified in the RIA (Table I). When fractions corresponding to peptides B or C were separated in the 1-propanol HPLC system, only one IR species was detected in each run (data not shown). This result is consistent with (but not proof of) the notion that peptide $\mathrm{B}$ and peptide $\mathrm{C}$ each contain only one IR component.

SDS-PAGE and trypsinization. Fractions corresponding to peptides $\mathrm{B}$ and $\mathrm{C}$ were pooled separately and
TABLE I

IR Leu-enk values of spinal cord extracts after HPLC separation After acid extraction and immunoprecipitation with the BF-GF antiLeu-enk antiserum, the spinal cord samples $(n=3)$ were submitted to HPLC with the $\mathrm{CH}_{3} \mathrm{CN}$ gradient system. Both BF-GF and BF-G (used in immunocytochemistry) quantified approximately the same concentrations of peptide $\mathrm{A}$, which had the same retention time as the pentapeptide Leu-enk. The BF-G RIA measured a smaller value for peptide $\mathrm{B}$ than did the BF-GF RIA, consistent with a lower affinity of BF-G for this peptide.

\begin{tabular}{|c|c|c|}
\hline \multirow{2}{*}{ Peptide } & \multicolumn{2}{|c|}{ Antiserum } \\
\hline & BF-GF & BF-G \\
\hline & \multicolumn{2}{|c|}{ fmol $\mathrm{mg}^{-1}$ protein } \\
\hline A & $215 \pm 19$ & $194 \pm 19$ \\
\hline B & $83 \pm 11$ & $54 \pm 9$ \\
\hline $\mathrm{C}$ & $33 \pm 5$ & $-{ }^{a}$ \\
\hline
\end{tabular}

${ }^{a}$ Since peptide $\mathrm{C}$ did not run parallel in the BF-G RIA, a comparison of values with the BF-GF RIA cannot be reported accurately.

lyophilized, and aliquots were subjected to (1) SDSPAGE and then (2) trypsinization, followed by HPLC analysis of the tryptic digests. In three SDS-PAGE individual runs prior to trypsinization, peptides $\mathrm{B}$ and $\mathrm{C}$ exhibited apparent molecular weights of $4,720 \pm 400$ and $31,000 \pm 1,200$, respectively. These values must be viewed with caution because of the anomalous behavior of basic proteins and glycoproteins in this system and the unknown chemical nature of these peptides. Tryptic digests of peptides $B$ and $C$ each revealed a single peak of IR Leu-enk activity when quantified with RIA using BF-G and BF-GF. The IR fragment generated from peptide $B$ exhibited the same retention time as authentic Leu-enk and both antisera quantified equal amounts of this peptide (intra-assay variation of $8.9 \%$ ) (Fig. 32). On the other hand, HPLC analysis of peptide C tryptic digests revealed no IR material at the position of Leu-enk but did show a single peak of immunoreactivity eluting with the retention time of synthetic Leu-enk-Arg ${ }^{6}$ (Fig. 32). The BF-GF RIA yielded a higher value for this material than did BF-G, in line with the lower affinity of BF-G for peptides without a free terminal leucine residue (Table I).

\section{Discussion}

The present study has identified immunoreactive Leuenkephalin-containing neuronal elements in the monkey spinal cord. Our results in the monkey are in general agreement with previous reports in the rat on the distribution of Met- and Leu-enkephalin fibers (Elde et al.,

Figure 17. Axodendritic synapse. A lightly stained large enkephalin dendrite $(D)$ receives a long surface synaptic contact from a terminal $(P)$ which is densely packed with pleomorphic vesicles and emerges from a myelinated process. Scale, $0.5 \mu \mathrm{m}$.

Figure 18. Type $\mathrm{C}$ terminal input to both IR and unlabeled dendrites. Large bouton $(C)$ with many small clear and large granular vesicles synapses with dendritic spine $(S)$ and IR Leu-enk dendrite $(D)$. The latter contains a few small clear (ringed arrow) and large granular (arrow) vesicles. Scale, $0.5 \mu \mathrm{m}$.

Figure 19. Dendrodendritic synapse. Leu-enk profile $D_{l}$ was identified as a dendrite by the presence of numerous microtubules which are lightly labeled with peroxidase reaction product and by its postsynaptic position to axon terminal, $P . D_{l}$ contains some vesicles (crossed arrow) and synapses (arrow) with dendrite $D_{2}$ which is also postsynaptic to a round vesicle profile $(R)$ at the ringed arrow. Scale, $0.5 \mu \mathrm{m}$.

Figure 20. Small IR Leu-enk profile. An immunostained element which is probably a dendrite is typical of those frequently seen throughout laminae I and II neuropil. This one receives synaptic input from axon, $P f$, which contains flat vesicles. Scale, 0.5 $\mu \mathrm{m}$. 

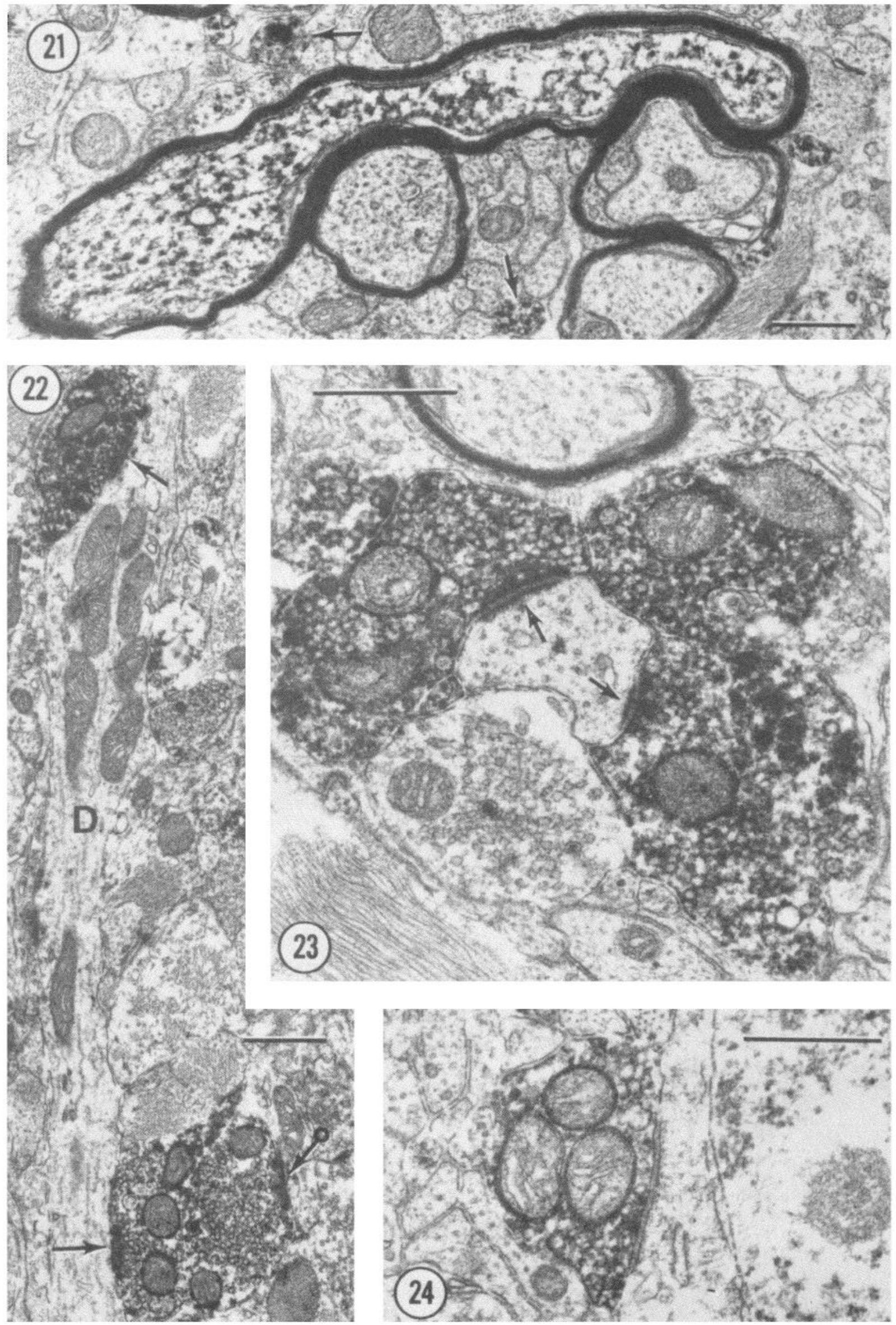

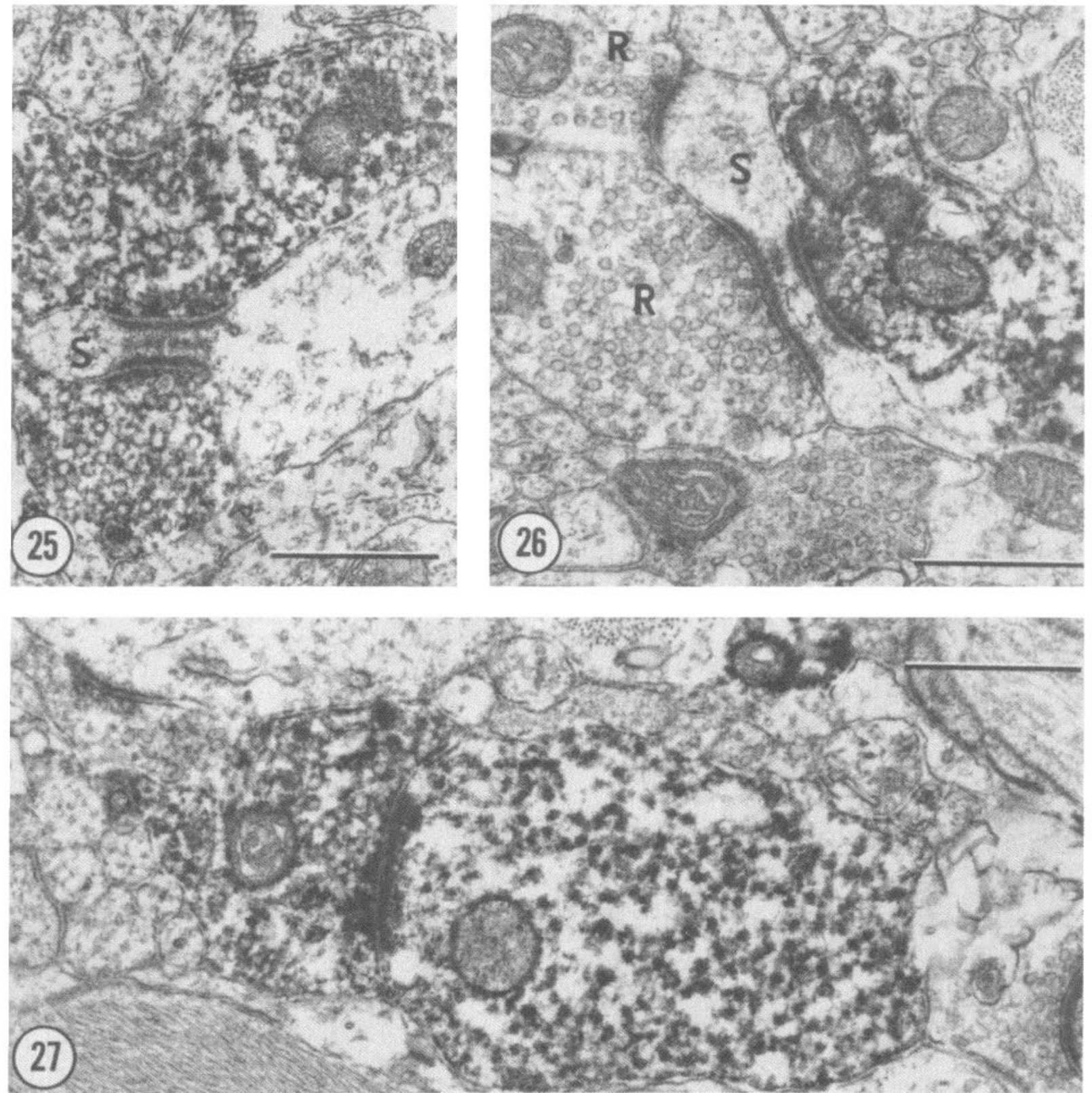

Figure 25. Axospinous synapse. IR Leu-enk terminal surrounds and synapses with the neck of a dendritic spine ( $S$ ). Scale, 0.5 $\mu \mathrm{m}$.

Figure 26. Converging axospinous synapses. An IR terminal and two unlabeled profiles with round vesicles $(R)$ contact the same dendritic spine $(S)$. Scale, $0.5 \mu \mathrm{m}$.

Figure 27. Interactions between IR enk profiles. An immunostained bouton forms an asymmetric synapse with an IR Leu-enk dendrite. Scale, $0.5 \mu \mathrm{m}$.

Figure 21. Myelinated axon. A thinly myelinated, small diameter axon immunostained for Leu-enk is near unstained myelinated axons of similar dimensions. Note the fine diameter, unmyelinated IR Leu-enk fibers (arrows). Scale, $0.5 \mu \mathrm{m}$.

Figure 22. IR Leu-enk terminals in lamina I. Two darkly stained boutons synapse (arrows) with the same dendrite, $D$. Terminal at top contains many LGV in addition to numerous small clear vesicles. Note also the axodendritic synapse (ringed arrow) made by another IR bouton. Scale, $0.5 \mu \mathrm{m}$.

Figure 23. Features of IR Leu-enk axon terminals. Immunolabeled boutons contain numerous round vesicles and a few LGV. Reaction product is present on the membranes of the small clear vesicles, the outer membranes of mitochondria, and within the LGV. Two of the boutons form asymmetric synapses (arrows) with a small dendrite in lamina I. Scale, $0.5 \mu \mathrm{m}$.

Figure 24. Axosomatic synapse. An IR Leu-enk bouton synapses with unlabeled soma in the substantia gelatinosa. Scale, 0.5 $\mu \mathrm{m}$. 

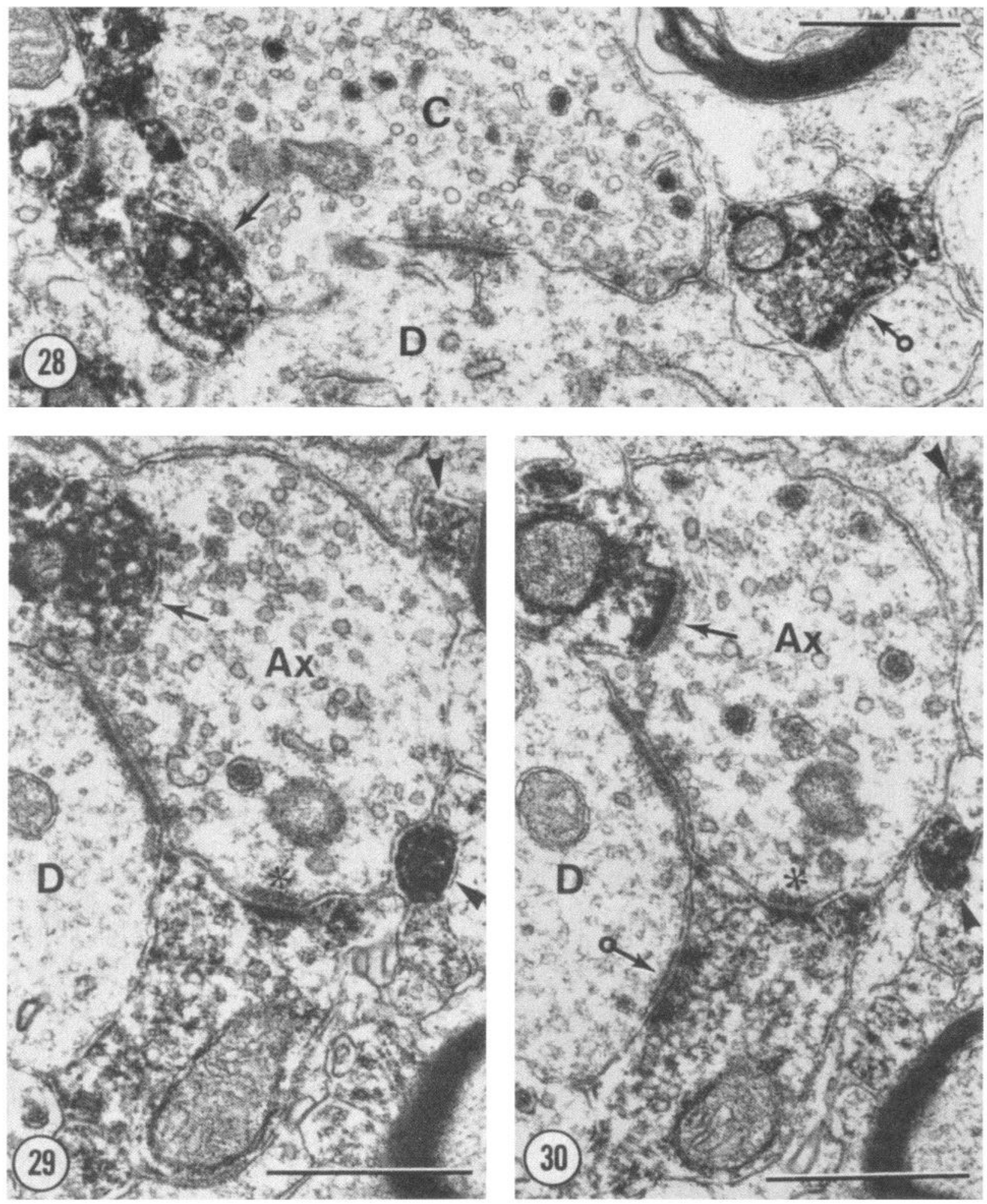

Figure 28. Axoaxonic synapse. A small enk-labeled bouton is filled with vesicles and synapses (arrow) with type C profile ( $C$ ), which contacts dendrite $D$. Note synapse formed by another IR axon at the ringed arrow. Scale, $0.5 \mu \mathrm{m}$.

Figures 29 and 30. Axoaxonic and axodendritic synapses in serial sections. In Figure 29, a small darkly labeled Leu-enk profile contains vesicles, some of which appear as lucent spherical elements. The bouton invaginates axon terminal, $A x$, at the arrow, and several sections away in Figure 30, it appears to form a synapse in the same location (arrow). In both sections, $A x$ synapses with dendrite $D$. Another lightly stained IR enk bouton also contacts $D$ (ringed arrow) and shares a punctum adhaerens with $A x$ $(*)$. $A x$, although smaller in size, has features in common with the type C terminal in Figure 28 . Note also the unmyelinated IR enk axons of small diameter (arrowheads). Scales, $0.5 \mu \mathrm{m}$. 


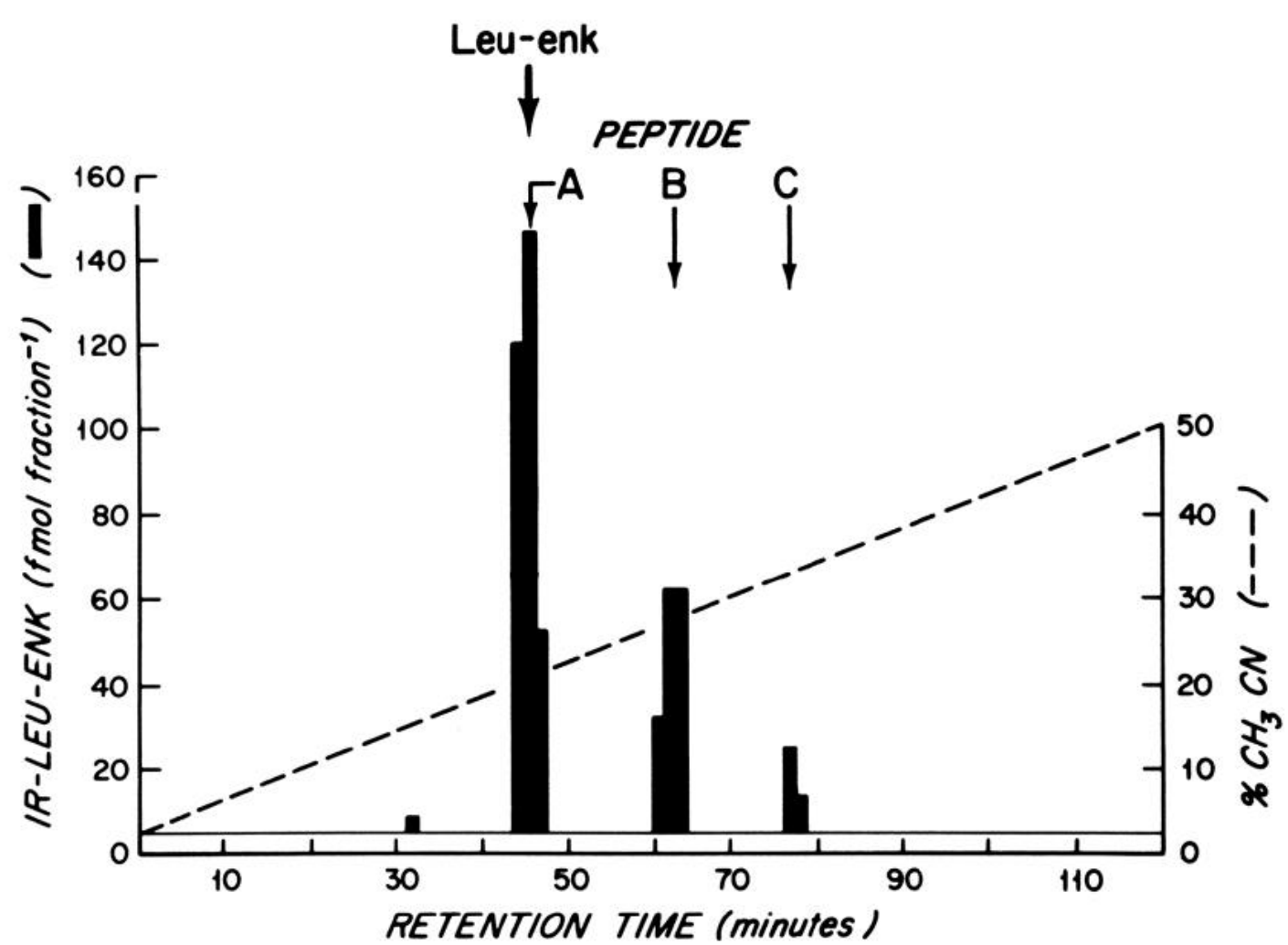

Figure 31. Reverse phase high pressure liquid chromatography of partially purified monkey spinal cord extract. After sample injection, $0.05 \mathrm{M}$ formate/triethylamine was pumped at a flow rate of $1 \mathrm{ml} \mathrm{min} \mathrm{m}^{-1}$ for $10 \mathrm{~min}$ (not shown in illustration). A 2-hr linear gradient elution from 2.5 to $50 \%$ $\mathrm{CH}_{3} \mathrm{CN}$ was performed then. Samples were lyophilized and reconstituted with RIA buffer, and aliquots were assayed in the Leu-enk RIAs. The data depicted were obtained with the BF-GF antisera. The BF-G RIA detected an equal amount of activity in the peptide A peak and approximately $47 \%$ of the activity in peptide B peak, compared to the BF-GF RIA. Peptide C was detected poorly and reacted in a nonparallel manner in the BF-G RIA. The thick arrow indicates the elution position of authentic Leu-enk.

1976; Watson et al., 1977; Simantov et al., 1977; Sar et al., 1978) and neurons (Hökfelt, 1977a) in laminae I and II. In a preliminary report in the cat, most IR Leu-enk somata have been found in the marginal layer (Glazer and Basbaum, 1979). In this study, neurons that contain Leu-enk were located primarily in laminae I and II and less frequently in laminae III and V. Previous studies have shown that cells in the dorsal laminae give rise to fibers that ascend several segments via the dorsolateral funiculus or tract of Lissauer and terminate in the marginal layer and substantia gelatinosa (Szentágothai, 1964; Denny-Brown et al., 1973; Kerr, 1975; Narotzky and Kerr, 1978; Cervero et al., 1979) or occasionally cross in the posterior commissure to end in the contralateral substantia gelatinosa (Szentágothai, 1964). It is possible that some IR Leu-enk somata contribute to these intersegmental connections. The presence of labeling for Leu-enk in the dorsolateral funiculus and the posterior and anterior commissures provides some evidence for this pathway. Furthermore, the numerous IR Leu-enk terminals are probably intrinsic and not the collaterals of primary afferents, since enkephalin immunostaining in spinal cord remains unchanged after dorsal rhizotomy (Hökfelt et al., 1977b).

Some cells in the brainstem have been found to stain with Met-enk and to project to the dorsal horn (Hökfelt et al., 1979). It is possible that some of the enkephalin terminals observed in our study belong to this pathway. Although descending pathways which may course in the dorsolateral funiculus (Burton and Loewy, 1977; Basbaum et al., 1978) have been demonstrated to modulate nociception in spinal cord of monkey (Willis et al., 1977) and cat (Fields et al., 1977; Carstens et al., 1980), the specific contribution made by descending enkephalin fibers is unknown.

Our electron microscopic findings showed that IR Leuenk neurons were contacted by at least four types of vesicle-containing profiles. The type $R$ and type $C$ boutons have the appearance of axon terminals similar to those identified by Ralston and Ralston (1979) as originating from the dorsal root. In general, primary afferent nociceptive axons have been thought to terminate within laminae I and II (Light and Perl, 1979a; Light et al., 1979) and, to a lesser extent, in other parts of the dorsal horn, including lamina V (Light and Perl, 1979b). It is likely, therefore, that a major input to the enkephalin neuron is provided by primary sensory axons.

Leu-enk axons form numerous axosomatic and axodendritic synapses with unlabeled cell bodies, dendrites, and spines in the superficial dorsal horn of the monkey spinal cord. These findings are in agreement with the types of synapses made by IR Met-enk terminals in the rat spinal 


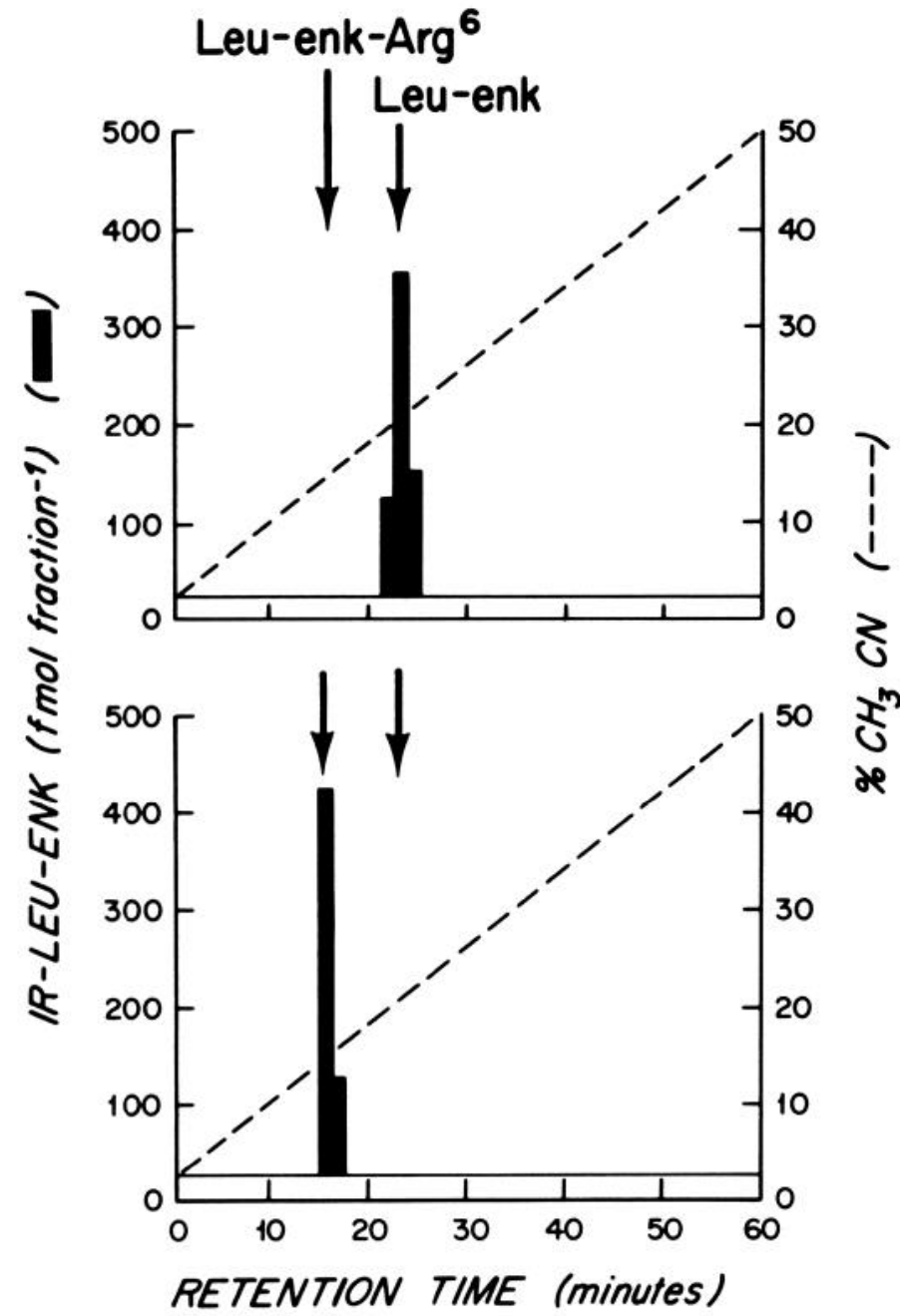

Figure 32. Reverse phase high pressure liquid chromatography of tryptic digests of peptide $\mathrm{B}$ and peptide $\mathrm{C}$ obtained from the HPLC chromatogram of partially purified monkey spinal cord extracts. IR Leu-enk eluting in the regions designated peptide $\mathrm{B}$ and peptide $\mathrm{C}$ (see Fig. 31) were pooled, lyophilized, and trypsinized overnight. The tryptic digests then were injected into the HPLC system, and the column was washed with $10 \mathrm{ml}$ of $0.05 \mathrm{M}$ formate/triethylamine and then eluted with a 1 -hr linear gradient from 2.5 to $50 \% \mathrm{CH}_{3} \mathrm{CN}$. All fractions were quantified in the BF-GF Leu-enk RIA. The arrows indicate the elution positions of synthetic Leu-enk-Arg ${ }^{6}$ and Leu-enk standards.

cord (Hunt et al., 1980). In addition, dendrites contacted by IR Leu-enk terminals also received input from type $\mathrm{C}$ or type $\mathrm{R}$ boutons. It is possible that neurons with such convergent inputs are projecting cells, since it is now thought that many neurons in lamina I (Trevino et al., 1973; Trevino and Carstens, 1975; Kumazawa et al., 1975) and some in lamina II (Giesler et al., 1978; Willis et al., 1978) contribute to ascending long spinosensory tracts. A similar synaptic relationship may be present in laminae IV and V, where cell bodies are known to contribute to the spinothalamic tract (Trevino et al., 1973; Trevino and Carstens, 1975) and where a labeling for IR Leu-enk fibers exists. Furthermore, distal dendrites from laminae IV and $\mathrm{V}$ cells in cat extend into the dorsal layers (Mannen, 1975), where they may be contacted by both local primary afferents and enkephalin terminals. In fact, enkephalin, when applied iontophoretically to the substantia gelatinosa, has been found to inhibit the effects of nociceptive stimuli in lamina IV or V neurons (Duggan et al., 1977).

Some Leu-enk axons appear to form synapses with type $\mathrm{C}$ profiles, which have been identified previously as originating from the dorsal root ganglia (Ralston and Ralston, 1979). In addition, results from our laboratory in the monkey indicate that type $\mathrm{C}$ terminals label for substance P (Leeman et al., 1980). Together, these findings provide evidence for a direct influence by enkephalin upon nociceptive primary afferents. It should be noted, however, that, in monkey, axoaxonic synapses are uncommon in laminae I and II ( 0.3 and $1 \%$ of all contacts, respectively; Ralston, 1979). They are more common in lamina III $(4 \%)$ and have been described recently in laminae IV to VI (Ralston et al., 1980). Although we did not examine more ventral laminae, it would appear improbable that many IR Leu-enk axons contact primary nociceptive afferents in these deeper layers, where both the dorsal root axons (Light and Perl, 1979a) and IR Leuenk fibers are far less numerous.

Based on the present anatomical findings, a model of sensory modulation by enkephalin within the spinal cord can be formulated. Enkephalin neurons, whose dendrites are contacted by primary afferents, synapse upon cells which also receive extrinsic input and which, in turn, contribute fibers to the spinothalamic tract. This scheme of a proposed postsynaptic site of action of Leu-enk is consistent with the demonstration that the peptide blocks glutamate-induced excitation (a postsynaptic phenomenon) within the spinal cord (Zieglgänsberger and Tulloch, 1979). From this circuit, it may be speculated that enkephalin binds mostly to opioid receptors contained on dendrites from cells within the spinal cord. Direct synapses by enkephalin axons with primary afferent terminals form a secondary site of interaction. Such modulation agrees with reports that show some reduction in opioid receptor binding following dorsal rhizotomy in the monkey (LaMotte et al., 1976) and rat (Jessell et al., 1979).

Some of the dendrites stained with Leu-enk contained vesicles and formed synapses, suggesting that the peptide may be released from dendrites as well as axon terminals. Presynaptic dendrites have been recognized in various parts of the central nervous system (see Ralston, 1971), including the spinal trigeminal nucleus of the cat (Gobel, 1976) and the monkey dorsal horn (Ralston, 1979). Iit general, they have been correlated with the axon-like appendages arising from the dendrites of Golgi type II interneurons seen at the light microscopic level. Such processes have been observed along the dendrites of gelatinosa neurons (Beal and Cooper, 1978). Thus, it is likely that some of the Leu-enk-stained varicosities observed in the light microscope in this and other immunocytochemical studies are dendritic and not axonal processes.

Our results show that there are synaptic connections between enkephalin-containing interneurons in the dorsal horn. Extensive interconnections between gelatinosa cells have been described (for review, see Kerr, 1975). 
The role of Leu-enk in such intrinsic connections is unclear.

Most of the axon terminals with Leu-enk immunoreactivity contained round vesicles and formed asymmetric contacts. Round vesicle profiles are the most frequent kind within the dorsal horn and most persist after dorsal rhizotomy (Ralston and Ralston, 1979). Although this type of bouton classically is associated with excitation, numerous exceptions do exist (Peters et al., 1976). The failure to observe asymmetric contacts formed by IR Met-enk terminals in the rat dorsal horn has been attributed by Hunt et al. (1980) to suboptimal fixation.

Biochemical analysis of spinal cord with the antiserum employed for immunocytochemistry (BF-G) indicated that a peptide physicochemically similar to Leu-enk and two larger IR Leu-enk peptides were found in monkey spinal cord tissue. Although the largest peptide was recognized poorly with the BF-G antiserum, it is likely that, because of the much higher concentration of antiserum employed for immunocytochemistry, all of the IR molecular species were labeled by this procedure. Since immunocytochemical methods recognize only specific antigenic determinants and not exact structures, the benefit of companion biochemical characterization as provided in this study becomes essential. It should be noted that IR Leu-enk forms not detected by RIA also may have contributed to the specific immunohistochemical staining and that aldehyde fixation may have altered the antigenicity of the peptides biochemically identified in fresh tissue.

The trypsinization experiments showed that a family of peptides that contain Leu-enkephalin may be present in the spinal cord. These studies suggest that Leu-enk comprises the carboxyl terminus of peptide B (apparent $\left.M_{r}=4720 \pm 400\right)$, is preceded immediately by basic residues (Lys and/or Arg), and thus can be liberated by a single trypsin-like cleavage. Peptide $B$ appears to be similar (or identical) to the 4700-dalton adrenal medulla peptide (peptide I) recently described by Kimura et al. (1980), which comprises 39 amino acids and contains a trypsin-releasable Leu-enk sequence at its $\mathrm{COOH}$ terminus as well as an internal Met-enk sequence. The peptide C (apparent $M_{r}=31,000$ ) found in this study may be related to the 50,000 -dalton adrenal medulla peptide identified by Lewis et al. (1980). They demonstrated that this latter peptide, or protein, contained seven copies of Met-enk and one copy of Leu-enk within its structure after treatment with trypsin followed by carboxypeptidase B digestion. Similar treatment of spinal cord peptide $\mathrm{C}$ should be expected to liberate free Leu-enk and possibly Met-enkephalin. Some of the peptides, or proteins, that contain Met- and/or Leu-enk sequences also may be present in the striatum (Stern et al., 1979), and it has been proposed that a common biosynthetic pathway exists for the enkephalins in a variety of tissues (Lewis et al., 1980). Our biochemical and immunocytochemical studies suggest the possibility that the larger IR enkephalin-like peptides may be present at presynaptic sites. Furthermore, it is possible that some of these larger peptides may be bioactive, as was recently shown by Rossier et al. (1980).

The immunocytochemical method employed in the present study appears not to allow description of details of subcellular sites for enkephalin labeling, particularly its specific localization to large granular vesicles (Pelletier and LeClerc, 1979). Our results show not only a deposition of reaction product in LGV but also varying degrees of precipitation surrounding small vesicles and other intracellular organelles and within the nucleus. Electron microscopic studies of Met-enk localization in the rat neostriatum (Pickel et al., 1980) have reported similar findings. It is interesting that, in studies where horseradish peroxidase is injected directly into cells (Beattie et al., 1978; Goode et al., 1980), the reaction product appears to be bound to several types of membranes including those of small vesicles and mitochondria. A major issue for further investigation, therefore, includes identification, within immunolabeled processes, of the contents of large and small vesicles with special attention to the possible coexistence of Leu-enk and conventional neurotransmitters, as demonstrated for other neuropeptides (Chan-Palay et al., 1978; Hökfelt et al., 1978).

\section{References}

Atweh, S. F., and M. Kuhar (1977) Autoradiographic localization of opiates and opiate receptors in rat brain. I. Spinal cord and medulla. Brain Res. 124: 53-67.

Basbaum, A. I., C. H. Clanton, and H. L. Fields (1978) Three bulbospinal pathways from the rostral medulla of the cat: An autoradiographic study of pain modulating systems. J. Comp. Neurol. 178: 209-224.

Beal, J. A., and M. H. Cooper (1978) The neurons in the gelatinosa complex (laminae II and III) of the monkey ( $\mathrm{Ma}$. caca mulatta): A Golgi study. J. Comp. Neurol. 179: 89-122.

Beattie, M. S., J. C. Bresnahan, and J. S. King (1978) Ultrastructural identification of dorsal root primary afferent terminals after antegrade filling with horseradish peroxidase. Brain Res. 153: 127-134.

Burton, H., and A. D. Loewy (1977) Projections to the spinal cord from medullary somatosensory relay nuclei. J. Comp. Neurol. 173: 773-792.

Carstens, E., D. Klumpf, and M. Zimmermann (1980) Time course and effective sites for inhibition from midbrain periaqueductal gray of spinal dorsal horn neuronal responses to cutaneous stimuli in the cat. Exp. Brain Res. 38: 425-430.

Cervero, F., A. Iggo, and V. Molony (1979) Ascending projections of nociceptor-driven lamina I neurons in the cat. Exp. Brain Res. 35: 135-149.

Chan-Palay, V., G: Jonsson, and S. L. Palay (1978) Serotonin and substance $P$ coexist in neurons of the rat's central nervous system. Proc. Natl. Acad. Sci. U. S. A. 75: 1582-1586.

Crain, S. M., B. Crain, E. R. Peterson, and E. J. Simon (1978) Selective depression by opioid peptides of sensory evoked dorsal-horn network responses in organized spinal cord cultures. Brain Res. 157: 196-201.

Denny-Brown, D., E. J. Kirk, and N. Yanagisawa (1973) The tract of Lissauer in relation to sensory transmission in the dorsal horn of the spinal cord in the macaque monkey. J. Comp. Neurol. 151: 175-200.

Duggan, A. W., J. Hall, and P. Headley (1977) Enkephalins and dorsal horn neurones of the cat: Effects on responses to noxious and innoxious skin stimuli. Br. J. Pharmacol. 61: 399-408.

Elde, R., T. Hökfelt, O. Johansson, and L. Terenius (1976) Immunohistochemical studies using antibodies to leucineenkephalin: Initial observations on the nervous system of the rat. Neuroscience 1: 349-351.

Fields, H. L., A. I. Basbaum, C. H. Clanton, and S. D. Anderson 
(1977) Nucleus raphe magnus inhibition of spinal cord dorsal horn neurons. Brain Res. 26: 441-453.

Giesler, G. V., Jr., J. T. Cannon, G. Urca, and J. C. Liebeskind (1978) Long ascending projections from substantia gelatinosa rolandi and the subjacent dorsal horn in the rat. Science 202: 984-986.

Glazer, E. J., and A. I. Basbaum (1979) Enkephalin perikarya in the marginal layer and sacral autonomic nucleus of the cat spinal cord. Soc. Neurosci. Abstr. 5: 2437.

Gobel, S. (1976) Dendroaxonic synapses in the substantia gelatinosa glomeruli of the spinal trigeminal nucleus of the cat. J. Comp. Neurol. 167: 165-176.

Goode, G. E., A. O. Humbertson, and G. F. Martin (1980) Projections from the brain stem reticular formation to laminae I and II of the spinal cord. Studies using light and electronmicroscopic techniques in the North American opossum. Brain Res. 18.9: 327-342.

Henry, J. L., B. J. Sessle, G. E. Lucier, and J. W. Hu (1980) Effects of substance $P$ on nociceptive and non-nociceptive trigeminal brainstem neurons. Pain 8: 33-45.

Hokfelt, T., and A. Ljungdahl (1972) Modification of the FalckHillarp formaldehyde fluorescence methods using the Vibratome: Simple, rapid and sensitive localization of catecholamines in sections of unified or formalin fixed brain tissue. Histuchemie 29: 324 .

Hökfelt, T., R. Elde, O. Johansson, L. Terenius, and L. Stein (1977a) The distribution of enkephalin-immunoreactive cell bodies in the rat central nervous system. Neurosci. Lett. 5: 25-31.

I Iökfelt, T., A. Ljungdahl, L. Terenius, R. Elde, and G. Nilsson (1977b) Immunohistochemical analysis of peptide pathways possibly related to pain and analgesia: Enkephalin and substance P: Proc. Natl. Acad. Sci. U. S. A. 74: 3081-3085.

Hökfelt, T., A. Ljungdahl, H. Steinbusch, A. Verhofstad, G. Nilsson, E. Brodin, B. Pernow, and M. Goldstein (1978) Immunohistochemical evidence of substance P-like immunoreactivity in some 5-hydroxytryptamine-containing neurons in the rat central nervous system. Neuroscience 3: 517538 .

Hökfelt, T., L. Terenius, H. G. J. M. Kuypers, and O. Dann (1979) Evidence for enkephalin immunoreactive neurons in the medulla oblongata projecting to the spinal cord. Neurosci. Lett. 14: 55-60.

Hughes, J., H. W. Kosterlitz, L. A. Fothergill, B. A. Morgan, and $H$. R. Morris (1975) Identification of two related pentapeptides from the brain with potent opiate agonist activity. Nature 258: 577-579.

Hunt, S. P., J. S. Kelly, and P. C. Emson (1980) The electron microscopic localization of methionine enkephalin within the superficial layers (I and II) of the spinal cord. Neuroscience 5: $1871-1890$.

Jessell, T., A. Tsunoo, I. Kanazawa, and M. Otsuka (1979) Substance P: Depletion in the dorsal horn of the rat spinal cord after section of the peripheral processes of primary sensory neurons. Brain Res. 168: 247-260.

Kerr, F. W. L. (1975) Neuroanatomical substrates of nociception in the spinal cord. Pain $1: 325-356$

Kimura, S., R. V. Lewis, A. S. Stern, J. Rossier, S. Stein, and S. Udenfriend (1980) Probable precursors of (Leu) enkephalin and (Met) enkephalin in adrenal medulla: Peptides of 3-5 kilodaltons. Proc. Natl. Acad. Sci. U. S. A. 77: 1681-1685.

Kosterlitz, H. W., and J. Hughes (1975) Some thoughts on the significance of enkephalin, the endogenous ligand. Life Sci. 17: 91-96.

Kumazawa, T., E. R. Perl, P. R. Burgess, and D. Whitehorn (1975) Ascending projections from marginal zone (lamina I) neurons of the spinal dorsal horn. J. Comp. Neurol. 162: 112.
LaMotte, C., C. B. Pert, and S. H. Snyder (1976) Opiate receptor binding in primate spinal cord: Distribution and changes after dorsal root section. Brain Res. 112: 407-412.

Leeman, S. E., M. DiFiglia, and N. Aronin (1980) Neurotensin (NT) and substance P (SP) localization in monkey and rat spinal cord: Light and electron microscopy. Soc. Neurosci. Abstr. 6: 354

Lewis, R. V., S. Stein, L. D. Gerber, M. Rubenstein, and S. Udenfriend (1978) High molecular weight opioid-containing proteins in striatum. Proc. Natl. Acad. Sci. U. S. A. 75: 40214023.

Lewis, R. V., S. Stein, and S. Udenfriend (1979) Separation of opioid peptides utilizing high performance liquid chromatography. Int. J. Pept. Protein Res. 13: 493-497.

Lewis, R. V., A. S. Stern, S. Kimura, J. Rossier, S. Stein, and S. Udenfriend (1980) An about 50,000-dalton protein in adrenal medulla: A common precursor of met- and leu-enkephalin. Science 208: 1459-1461.

Light, A. R., and E. R. Perl (1979a) Re-examination of the dorsal root projection to the spinal dorsal horn including observations on the differential termination of coarse and fine fibers. J. Comp. Neurol. 186: 117-132.

Light, A. R., and E. R. Perl (1979b) Spinal termination of functionally identified primary afferent neurons with slowly conducting myelinated fibers. J. Cornp. Neurol. 186: 133-150.

Light, A. R., D. L. Trevino, and E. R. Perl (1979) Morphological features of functionally defined neurons in the marginal zone and substantia gelatinosa of the spinal dorsal horn. J. Comp. Neurol. 186: 151-172.

Liotta, A. S., and D. T. Krieger (1980) In vitro biosynthesis and comparative posttranslational processing of immunoreactive precursor corticotropin/ $\beta$-endorphin by human placenta and pituitary cells. Endocrinology 106: 1504-1511.

Liotta, A. S., D. Gildersleeve, M. J. Brownstein, and D. T. Krieger (1979) Biosynthesis in vitro of immunoreactive 31,000-dalton corticotropin/ $\beta$-endorphin-like material by bovine hypothalamus. Proc. Natl. Acad. Sci. U. S. A. 76: 14481452.

Lowry, O. H., N. J. Rosebrough, A. L. Farr, and R. J. Randall (1951) Protein measurement with the Folin phenol reagent. J. Biol. Chem. 193: 265-275.

Mannen, H. (1975) Reconstruction of axonal trajectory of individual neurons in the spinal cord using Golgi-stained serial sections. J. Comp. Neurol. 159: 357-374.

Mudge, A. W., S. E. Leeman, and G. D. Fischbach (1979) Enkephalin inhibits release of substance $P$ from sensory neurons in culture and decreases action potential duration. Proc. Natl. Acad. Sci. U. S. A. 76: 526-530.

Narotzky, R. A., and F. W. L. Kerr (1978) Marginal neurons of the spinal cord: Types, afferent synaptology and functional considerations. Brain Res. 139: 1-20.

Nicoll, R. A., C. Schenker, and S. E. Leeman (1980) Substance $P$ as a neurotransmitter candidate. Annu. Rev. Neurosci. 3: 227-268

Pelletier, G., and R. LeClerc (1979) Localization of leu-enkephalin in dense core vesicles of axon terminals. Neurosci. Lett. 12: 159-163.

Peters, A., S. L. Palay, and II. deF. Webster (1976) Fine Structure of the Nervous System: The Neurons and Supporting Cells, pp. 148-150, W. B. Saunders, Philadelphia.

Pickel, V. M., D. J. Reis, and S. E. Leeman (1977) Ultrastructural localization of substance $\mathrm{P}$ in neurons of rat spinal cord. Brain Res. 122: 534-540.

Pickel, V. M., K. K. Sumal, S. C. Beckley, R. J. Miller, and D. J. Reis (1980) Immunocytochemical localization of enkephalin in the neostriatum of rat brain: A light and electron microscopic study. J. Comp. Neurol. 189: 721-740.

Ralston, H. J., III (1971) Evidence for presynaptic dendrites 
and a proposal for their mechanisms of action. Nature 230: 585-587.

Ralston, H. J., III (1979) The fine structure of laminae I, II and III of the macaque spinal cord. J. Comp. Neurol. 184: 619642.

Ralston, H. J., and D. D. Ralston (1979) The distribution of dorsal root axons in laminae I, II and III of the macaque spinal cord: A quantitative electron microscope study. J. Comp. Neurol. 184: 643-684.

Ralston, H. J., III, A. R. Light, E. R. Perl, and D. D. Ralston (1980) The projection of dorsal root fibers to the deep dorsal horn of the macaque spinal cord, examined by degeneration, autoradiographic and intra-axonal labelling techniques. Anat. Rec. 196: 152A.

Rossier, J., Y. Audigier, N. Ling, J. Cros, and S. Udenfriend (1980) Met-enkephalin-like-Arg ${ }^{6}-\mathrm{Phe}^{7}$, present in high amounts in brain of rat, cattle and man, is an opioid agonist. Nature 288: 88-90.

Sar, M., W. E. Stumpf, R. J. Miller, K. -J. Chang, and P. Cuatrecasas (1978) Immunohistochemical localization of enkephalin in rat brain and spinal cord. J. Comp. Neurol. 181: $17-38$.

Simantov, R., M. J. Kuhar, G. W. Pasternak, and S. H. Snyder (1976) The regional distribution of a morphine-like factor enkephalin in monkey brain. Brain Res. 106: 187-197.

Simantov, R., M. J. Kuhar, G. W. Uhl, and S. H. Snyder (1977) Opioid peptide enkephalin: Immunohistochemical mapping in rat central nervous system. Proc. Natl. Acad. Sci. U. S. A. 74: $2167-2171$
Stern, A. S., R. V. Lewis, S. Kimura, J. Rossier, L. D. Gerber, L. Brink, S. Stein, and S. Udenfriend (1979) Isolation of the opioid heptapeptide met-enkephalin $\left[\mathrm{Arg}^{6}, \mathrm{Phe}^{7}\right]$ from bovine adrenal medullary granules and striatum. Proc. Natl. Acad. Sci. U. S. A. 6: 6680-6683.

Sternberger, L. A. (1974) Immunocytochemistry, Prentice-Hall, Englewood Cliffs, NJ.

Szentágothai, J. (1964) Neuronal and synaptic arrangements in the substantia gelatinosa rolandi. J. Comp. Neurol. 122: 219240.

Trevino, D. L., and E. Carstens (1975) Confirmation of the localization of spinothalamic neurons in the cat and monkey by the retrograde transport of horseradish peroxidase. Brain Res. 98: 177-182.

Trevino, D. L., J. D. Coulter, and W. D. Willis (1973) Location of cells of origin of spinothalamic tract in lumbar enlargement of the monkey. J. Neurophysiol. 36: 750-761.

Watson, S. J., H. Akil, S. Sullivan, and J. D. Barchas (1977) Immunocytochemical localization of methionine enkephalin: Preliminary observations. Life Sci. 21: 733-738.

Willis, W. D., L. H. Haber, and R. F. Martin (1977) Inhibition of spinothalamic tract cells and interneurons by brain stem stimulation in the monkey. J. Neurophysiol. 40: 968-981.

Willis, W. D., R. B. Leonard, and D. R. Kenshalo, Jr. (1978) Spinothalamic tract neurons in the substantia gelatinosa. Science 202: 986-988.

Zieglgänsberger, W., and I. F. Tulloch (1979) The effects of methionine and leucine-enkephalin on special neurones of the cat. Brain Res. 167: 53-64. 